\title{
Taiwanese Parents' Beliefs Regarding Young Children's Art Education and the Actual Art Achievements of Children
}

\author{
Ching-Yuan Hsiao ${ }^{1} \&$ Tzu-Chi Pai ${ }^{2}$ \\ ${ }^{1}$ Department of Early Childhood Education, National University of Tainan, Tainan, Taiwan \\ ${ }^{2}$ Kaohsiung Municipal Jhong-Jheng Elementary School, Kaohsiung, Taiwan \\ Correspondence: Ching-Yuan Hsiao, Department of Early Childhood Education, National University of Tainan, \\ 33, Sec. 2, Shu-Lin St., Tainan 700, Taiwan. Tel: 886-929-040-353. E-mail: cyh111@mail.nutn.edu.tw
}

\author{
Received: May 12, 2014 Accepted: June 20, 2014 Online Published: August 14, 2014 \\ doi:10.5539/ies.v7n9p24 URL: http://dx.doi.org/10.5539/ies.v7n9p24
}

\begin{abstract}
The research goal is to ascertain the current beliefs of the parents of preschool children regarding art education in Taiwan. Background factors on the parents were tested to show the differences between the parents' beliefs regarding art education and the actual art achievements of the children. From there, relationships between the beliefs and the actual achievements were analyzed and established. The researcher prepared the self-completion survey and distributed 300 copies to parents; 267 copies were returned with an effective return rate of $92.87 \%$. The findings were as follows:
\end{abstract}

I. Preschool parents viewed children's art education from four aspects-children's artistic development, children's art courses, parental art beliefs, and teachers' professionalism in art.

II. Differences in the art education beliefs of preschool parents with different background factors:

A. Parents from different types of preschools show significant differences in terms of the children's art curriculum.

B. Parents' gender shows significant differences toward their beliefs regarding art education.

C. Parents' education shows significance differences in the dimension of children's art courses.

D. The location of the family residence shows significant differences in parental beliefs regarding art education.

III. Differences in children's achievements in art education depend on the different background factors of the preschool parents:

A. The location of the family residence shows significant differences in children's art satisfaction.

IV. Parental approval of children's learning outcomes is in direct proportion to preschool parental beliefs regarding art education.

V. Preschool parental beliefs regarding art education are predictive of children's learning outcomes, especially in the area of children's art courses.

Keywords: art achievements in preschool classes, children's art education, parental beliefs

\section{Introduction}

The researcher has been teaching preschool art and aesthetic education for over a decade, and one observation is that parents with different characteristics often demonstrate completely different reactions to the aesthetic creations of their children. When the children's artworks are displayed in public by the teacher, the children are filled with excitement, and to share this excitement, they drag their parents or family to the see their artwork with the expectation of hearing words of approval. In situations like these, the researcher has observed all kinds of responses from the parents or families and summarizes them as the following three scenarios: (1) the parents or family immediately praise the children upon seeing their artwork: "Great job" or "It's beautifully done!" (2) The parents or family see the artwork and give a nod or verbal response: "So this is your work," indicating their awareness of the authorship of the artwork. (3) The parents or family would look at their children's artwork and provide negative and critical responses, such as "That doesn't look like a dog to me," "John's a much better painter than you," and "You messed the colors up". 
The above three scenarios actually happened and attracted the researcher to engage in an in-depth investigation of how parents look at preschool children's development in art. Sifting through and summarizing related literature, the researcher found that most studies on preschool art education have focused on the teachers' perspective of art education in Taiwan. However, only a few studies, most of which primarily targeted "after-school art classes", have explored the parents of these children. Some western researchers have proved that significant differences in the beliefs of children art education between parents of different background factors (Anning, 2002; Burkitt, Jolley, \& Rose, 2010; Elliot, 1987; Huntsinger, Jose, Krieg, \& Luo, 2011; Kantner \& Hoffman,1992; Rose, Jolle, \& Burkitt, 2006). There are still several stages concerning preschool art education that remain to be clarified in Taiwan. For example, how do parents look at current preschool art education? What background knowledge do these parents have in terms of preschool art education? Are the parents satisfied with the status quo of preschool art education? The purpose of this study is to investigate the correlation between the beliefs of preschool parents and the learning effectiveness of preschool art education. The results could be used to create a finer environment for preschool art education. Based on the motivation and purpose, the problems that are discussed in this study are as follows:

\subsection{Differences in the Beliefs of Preschool Art Education between Parents of Different Backgrounds}

1) Are there any significant differences in the beliefs regarding art education between parents choosing a different type of preschool?

2) Are there any significant differences in the beliefs regarding art education between parents of different genders?

3) Are there any significant differences in the beliefs regarding art education between parents of different educational backgrounds?

4) Are there any significant differences in the beliefs regarding art education between parents choosing a preschool or the location of the family residence?

1.2 Differences in the Beliefs Regarding the Views on Learning Effectiveness of Preschool Art Education between Parents of Different Backgrounds

1) Are there any significant differences in the learning effectiveness of the preschool art education when parents choose a different type of preschool?

2) Are there any significant differences in the learning effectiveness of the preschool art education between parents of different genders?

3) Are there any significant differences in the learning effectiveness of preschool art education between parents of different educational backgrounds?

4) Are there any significant differences in the learning effectiveness of preschool art education between parents choosing a preschool in relation to the location of the family residence?

1.3 What Are the Correlations between Preschool Parental Beliefs Regarding Art Education with Preschool Children's Learning Effectiveness?

1.4 What Is the Predictive Power of Preschool Parents'Beliefs Regarding Art Education on Preschool Children's Learning Effectiveness?

\subsection{Definition of Term}

Hsiao (2008) noted a "belief" has been considered as defying logic, inflexible, and unchanging. In this study, the beliefs indicate Taiwan parents of different genders, parents of different educational backgrounds, parents residing in different locations, and types of preschool those variables would impact on their interpretation of children's art and the actual art achievements of the children.

\section{Review of Selected Literature and Research}

\subsection{Preschool Art Courses}

Prior to the integration of preschools with nursery schools, preschool education adopted the curriculum revised and announced by the Ministry of Education in 1987, namely the Kindergarten Curriculum Standard. This covered the six major disciplines of health, play, music, working, language, and common knowledge. In the Standard, art was included in the "working" discipline, and covered painting, paper sculpture, sculpture, and crafts. This standard has been used since 1987 and the contents no longer satisfy the needs of modern education. Additionally, once the integration of preschools and nursery schools was completed, the Ministry of Education began to institute a preschool curriculum that corresponded with the modern trends and concepts. The result is 
the Temporary Curriculum Guidelines for Preschool Childcare and Education (MOE, 2013). The needs of preschool children and the expectations of society and culture mean that the curriculum is divided into six major disciplines: body movement and health, cognition, language, society, emotion, and the aesthetic domain. Among the disciplines, the aesthetic domain aims to cultivate preschool children's sensitivity toward daily objects in the surrounding environment, and to form personal preferences and a domain of aesthetics by arousing their profound potential in imagination and creativity (MOE, 2013). The preschool art courses referred to in this study are included in this aesthetic domain.

The contents of the six major domains of the Temporary Curriculum Guidelines for Preschool Childcare and Education are made up of domain expertise and learning facets. Each domain consists of the domain objectives, curriculum objectives and learning indicators for different age groups. Aesthetic education specifically nurtures the three major abilities of awareness and discovery, expression and creativity and response and appreciation, as well as the two learning orientations of aptitude and artistic medium (MOE, 2013).

Art education for preschoolers should be based on an integrative and open approach so that they can participate freely. Furthermore, the preschool art curriculum should provide for a comprehensive artistic creation environment, with integration between art and the curriculum, enabling the expression of the ideas of children through art-based activities. Self-reflection and a critical response to the artwork of peers should be encouraged. The mental and physical growth of children should be achieved through a holistic education (Koster, 2005; C. Lee \& H. Lee, 2006). In addition, Huang (2005) discovered that, with regard to the parental expectations of their children and the selection of their children's preschool education, parents who chose education for their child in a private preschool organization placed greater emphasis on the curriculum content, teaching methods, and organizational reviews when compared to those who selected public preschools.

\subsection{Parental Beliefs and Attitudes toward Art Education}

In the process of children's art education, the role of parents should be one that provides assistance and encouragement, support and respect, so as to allow the creations of a child to reach the realization of aesthetic experience and life. It should not be to instill the stress of competitive ranking, which will impede the development of the child. The main objective of art education is not to develop a professional drawing talent, but to nurture a child's interest and attitude towards art appreciation. In the meantime, the holistic development of the child should be nurtured. As such, many experts advise parents to provide suggestions in art learning for their children.

Furthermore, Lowenfeld (1954) mentioned how parents should develop the artistic talent of their child in his book Your Child and His Art. Parents should first understand and know the needs and wants of the child, and develop his sensitivity to his surrounding environment. Lowenfeld (1954) also stated when working with the child in a creative activity, parents should develop the graciousness for mutual respect for the artworks of one another. If space is sufficient, parents should let the child hang all his artwork on the wall. Parents should also encourage the child to develop his creative skills through experimental methods. In a general overview of the relevant Taiwanese studies, there are a limited number of studies that discuss the parent-child relationship from the aspect of art talent (Pai, 2014). Only Li (2006) used the preschools of the Taipei municipality as a case study to investigate the factors that affect parental selection of a child's after-school art classes. Hsiao and Kuo (2013) examined the relationship between the factors affecting parental selection of after-school art classes and preschool talent classes in an urban area, and Lai (2011) looked at the case studies of parental guidance in children's artistic learning. The most relevant points in parent-child art education are as follows:

1) $\mathrm{Li}$ (2006) discovered that preschool parents select after-school art classes for their children based on their age; the gender of the child has minimal influence. The age and educational backgrounds of the parents, amongst other background factors, are the main factors that influence the selection of after-school art activities for the child.

2) Hsiao and Kuo (2013) discovered that the type of preschool and educational background of the parents show a significant difference and influence on the selection of the kinds of after-school art classes. Public preschool parents place a greater emphasison teaching factors, which involve the teaching methods and skills of the art teacher, teaching curriculum and content, and understanding the child's development, when compared to private preschool parents.

3) Lai (2011) discovered that the main problem that parents face regarding the art teaching of their child is due to "insufficient professional knowledge in art education".

In addition, other studies regarding child education beliefs and teaching effectiveness include: 
4) $\mathrm{Wu}(2002)$ discovered that parents with different levels of education between the mother and father have significant differences in the educational beliefs of their children; the higher the educational level of the parent, the greater emphasis on the development of the specialties of the child. From the aspect of participation in the education of the child, mothers are significantly more involved in the learning activities of the child compared to the fathers.

5) Zheng (2009) discovered that the gender of the parents of elementary school children and the location of schools show a significant difference at all levels of after-school art classes.

6) Liu (2013) discovered that the higher the educational expectations of the elementary school parents of their children, the higher the acknowledgement of talent learning. However, there is no significant difference towards their children's after-school art classes' expectation of parents of different age groups/genders. The parental lack of adequate art education values and understanding of the stages of the physical and mental development of children will result in over-expectation and over-estimation of the teaching and expectations of the child. This will negatively influence the motivation and interest of the children's learning. Parents are the most important initial educators when children are toddlers. However, they must first understand the physical and psychological development stages of a child before being able to provide adequate guidance and a holistic learning environment (Lowenfeld \& Brittain, 1987), thereby allowing the children to realize their potential and ensure the development of a healthy character.

\section{Methods}

This study adopted a quantitative approach and conducted a self-completed questionnaire, entitled "preschool parents' beliefs regarding children's art education and children's art achievements". The following section describes the research participants, sampling methods, questionnaire design, reliability and validity of the questionnaire, and the data analysis process.

\subsection{Research Participants and Sampling Methods}

This study surveyed parents of public and private preschool students through questionnaires, which were distributed using the snowball sampling method. The researcher commissioned known preschool directors and teachers to distribute the questionnaire to parents and to introduce another group of preschool directors and teachers who were also willing to assist in distributing the questionnaires. A total of 300 parents of preschool children were selected as the research population. The collected questionnaires numbered 297 in total, with 267 valid questionnaires. The return rate was $97.97 \%$, with a valid rate of $92.87 \%$.

\subsection{Questionnaire Design}

The first part of the questionnaire concentrated on the demographical information of the parents. The parents were asked to check the option that best corresponded to the status of the respondent. The second part concentrated on the creative experience in children's art. A Likert seven-point scale was incorporated for the respondents to choose the most appropriate choices. The third part, satisfaction of preschool children's learning effectiveness of art, was composed of three questions in the form of a Likert seven-point scale. A high value for totaled scores indicated the greater satisfaction of the responding parent for their child with regards to the effectiveness of learning art. The fourth part, concentrating on the importance of preschool art, was composed of 50 questions, also in the form of a Likert seven-point scale. Sauro (2010) stated adapting seven points tends to be a good balance between having enough points of discrimination without having to maintain too many response options. The same part also included an open question and a multiple-choice question.

\subsection{The Reliability and Validity of the Questionnaire}

\section{1) Expert content validity}

Five scholars and experts were invited to examine the validity of the questionnaire. They were also asked to provide alternative suggestions as a reference for revision. After the expert validity questionnaires were collected, the suggestions were referenced to revise the content and wording of the first draft of the questionnaire to establish expert validity. Moreover, a pre-test was administered to enhance the content validity.

2) The reliability of the questionnaire

An internal consistency analysis was conducted on the results of the entire scale. The Cronbach's $\alpha$ of the entire scale was 0.931 . According to Nunnally (1978), Cronbach's $\alpha$ should be at least 0.70 to be reliable. Thus, this study demonstrated good reliability. 


\subsection{Data Analysis}

When the questionnaires were collected, respondents who provided incomplete information or who had checked the same answers throughout the questionnaire were deleted. The results of valid questionnaires were then coded and entered into the computer. SPSS 19.0 was used for statistical analysis to verify the questions to be answered. This study utilized the following data analysis methods: One-way analysis of variance (one-way ANOVA), t-test, Scheffé method, Pearson product-moment correlation coefficient, and multiple regression analysis.

\subsection{Interviewees}

In addition to administering the questionnaire survey, the data collection process of this study also involved a field experiment in which parents in the suburban and urban area were interviewed as part of the data analysis. During the process of choosing interviewees and entering the questionnaire results, it was found that six parents provided penetrating answers in the open question sections. Since it was necessary to scrutinize their answers, these parents were also included in the interviewee population. The researcher made two interview questions: Do you have any comments regarding Taiwanese children's art education in preschools? What's your suggestions regarding Taiwanese children's art education in preschools? And then, the research interviewed each parent 30 minutes. The transcripts of interviews are to assist the researcher in the quantitative data analysis.

\section{Results and Analyses of the Findings}

\subsection{Differences in Parents from Various Backgrounds and the Beliefs Regarding Preschool Art Education}

This section investigated whether preschool parents from different backgrounds showed differences in their beliefs regarding preschool art education. The background factors included four variables: type of preschool, gender of the parent, educational background of the parent, and the location of their residence. Parental beliefs regarding art education included four factors: preschool art courses, children's artistic development, parental beliefs regarding art education, and professional knowledge of preschool art teachers.

4.1.1 Analysis of the Differences in the Beliefs of Preschool Art Education between Parents of Different Background Factors

1) Analysis of the differences in the beliefs regarding art education between parents choosing different types of preschool

The data in Table 1 shows the descriptive statistics and t-test results for the beliefs regarding art education between parents choosing different types of preschool. The factors were categorized into two types: (1) public preschool and (2) private preschool. A t-test was conducted to verify the differences in the beliefs regarding art education between parents choosing different types of preschool.

Table 1. Descriptive statistics and t-test results for the beliefs regarding art education between parents choosing different types of preschool $(n=267)$

\begin{tabular}{|c|c|c|c|c|c|c|}
\hline Factors & Levels & $\mathrm{N}$ & $\mathrm{M}$ & SD & $\mathrm{t}$-value & Sig. \\
\hline \multirow{2}{*}{ Preschool art courses } & Public & 71 & 5.90 & 0.59 & \multirow{2}{*}{-2.738} & \multirow{2}{*}{$0.007 * *$} \\
\hline & Private & 196 & 6.10 & 0.50 & & \\
\hline \multirow{2}{*}{ Children's artistic development } & Public & 71 & 6.04 & 0.55 & \multirow{2}{*}{-1.569} & \multirow{2}{*}{0.118} \\
\hline & Private & 196 & 6.16 & 0.53 & & \\
\hline \multirow{2}{*}{ Parents' beliefs regarding art education } & Public & 71 & 5.65 & 0.63 & \multirow{2}{*}{-0.785} & \multirow{2}{*}{0.433} \\
\hline & Private & 196 & 5.72 & 0.61 & & \\
\hline \multirow{2}{*}{ Professional knowledge of preschool art teachers } & Public & 71 & 5.69 & 0.71 & \multirow{2}{*}{0.487} & \multirow{2}{*}{0.627} \\
\hline & Private & 196 & 5.65 & 0.64 & & \\
\hline \multirow{2}{*}{$\begin{array}{l}\text { The entire scale of parents' beliefs regarding art } \\
\text { education }\end{array}$} & Public & 71 & 6.52 & 0.61 & \multirow[t]{2}{*}{-0.905} & \multirow[t]{2}{*}{0.366} \\
\hline & Private & 196 & 6.59 & 0.54 & & \\
\hline
\end{tabular}

$* \mathrm{p}<.05, * * \mathrm{p}<.01$

Table 1 data indicates that parents choosing different types of preschool demonstrated a significant difference in the preschool art courses factor. Parents of private preschool children scored significantly higher than those of 
public preschools, whereas in other factors no significant difference was found in parents choosing a different type of preschool.

2) Analysis of the differences in the beliefs regarding art education between parents of different genders

The data in Table 2 reveals the descriptive statistics and t-test results of the beliefs regarding art education between parents of different genders. The factors were categorized into two types: (1) female and (2) male. A t-test was conducted to verify the differences in the beliefs regarding art education between parents of different genders.

Table 2. Descriptive statistics and t-test results of the beliefs regarding art education between parents of different genders $(\mathrm{n}=267)$

\begin{tabular}{lllllll}
\hline Factors & Levels & $\mathrm{N}$ & $\mathrm{M}$ & $\mathrm{SD}$ & t-value & Sig. \\
\hline \multirow{2}{*}{ Preschool art courses } & $\mathrm{F}$ & 210 & 6.09 & 0.52 & \multirow{2}{*}{3.056} & \multirow{2}{*}{$0.002 *$} \\
& $\mathrm{M}$ & 57 & 5.85 & 0.56 & & \\
\hline \multirow{2}{*}{ Children's artistic development } & $\mathrm{F}$ & 210 & 6.16 & 0.53 & \multirow{2}{*}{2.151} & \multirow{2}{*}{$0.032 *$} \\
\hline Parents' beliefs regarding art education & $\mathrm{M}$ & 57 & 5.99 & 0.55 & & \\
\hline \multirow{2}{*}{ Professional knowledge of preschool art teachers } & $\mathrm{F}$ & 210 & 5.74 & 0.60 & \multirow{2}{*}{1.931} & \multirow{2}{*}{0.055} \\
& $\mathrm{M}$ & 57 & 5.56 & 0.64 & & \\
\hline \multirow{2}{*}{ The entire scale of parents' beliefs regarding art education } & $\mathrm{F}$ & 210 & 5.71 & 0.59 & \multirow{2}{*}{2.391} & \multirow{2}{*}{$0.017 *$} \\
& $\mathrm{M}$ & 57 & 5.48 & 0.84 & & \\
\hline
\end{tabular}

$* \mathrm{p}<.05$

Table 2 data indicates that parents of different genders demonstrated significant differences in the factors of preschool art courses, children's artistic development, professional knowledge of preschool art teachers, and the entire scale of parents' beliefs regarding art education. Female parents scored significantly higher in the factors of preschool art courses, children's artistic development, professional knowledge of preschool art teachers, and the entire scale of parents' beliefs regarding art education, whereas in the factor of parents' beliefs regarding art education no significant difference was found in parents of different genders.

3) Analysis of the differences in the beliefs regarding art education between parents of different educational backgrounds

The data in Table 3 shows the descriptive statistics and ANOVA results for the beliefs regarding art education between parents of different educational backgrounds. The factors were categorized into five types: (1) elementary school; (2) junior high school; (3) senior high school; (4) college or university; and (5) graduate school and above. An ANOVA was conducted to verify the differences in the beliefs regarding art education between parents of different educational backgrounds. 
Table 3. Descriptive statistics and ANOVA results of the beliefs regarding art education between parents of different educational backgrounds $(n=267)$

\begin{tabular}{|c|c|c|c|c|c|c|c|}
\hline Factors & Levels & $\mathrm{N}$ & $\mathrm{M}$ & SD & $\mathrm{F}$ & Sig. & Scheffé \\
\hline \multirow{6}{*}{ Preschool art courses } & 1. Elementary school & 2 & 4.85 & 0.11 & \multirow{6}{*}{3.836} & \multirow{6}{*}{$0.005 * *$} & \multirow{6}{*}{$\begin{array}{l}4>1 \\
5>1\end{array}$} \\
\hline & 2. Junior high school & 5 & 5.57 & 0.71 & & & \\
\hline & 3. Senior high school & 27 & 6.03 & 0.50 & & & \\
\hline & 4. College or university & 166 & 6.05 & 0.51 & & & \\
\hline & $\begin{array}{l}\text { 5. Graduate school or } \\
\text { above }\end{array}$ & 67 & 6.09 & 0.55 & & & \\
\hline & Total & 267 & 6.04 & 0.53 & & & \\
\hline \multirow{6}{*}{ Children's artistic development } & 1. Elementary school & 2 & 5.35 & 0.64 & \multirow{6}{*}{1.818} & \multirow{6}{*}{0.126} & \\
\hline & 2. Junior high school & 5 & 5.86 & 0.69 & & & \\
\hline & 3. Senior high school & 27 & 6.20 & 0.48 & & & \\
\hline & 4. College or university & 166 & 6.15 & 0.54 & & & \\
\hline & $\begin{array}{l}\text { 5. Graduate school or } \\
\text { above }\end{array}$ & 67 & 6.06 & 0.53 & & & \\
\hline & Total & 267 & 6.12 & 0.54 & & & \\
\hline \multirow{6}{*}{$\begin{array}{l}\text { Parents' beliefs regarding art } \\
\text { education }\end{array}$} & 1. Elementary school & 2 & 4.88 & 0.18 & \multirow{6}{*}{1.664} & \multirow{6}{*}{0.159} & \\
\hline & 2. Junior high school & 5 & 5.40 & 0.49 & & & \\
\hline & 3. Senior high school & 27 & 5.73 & 0.70 & & & \\
\hline & 4. College or university & 166 & 5.74 & 0.59 & & & \\
\hline & $\begin{array}{l}\text { 5. Graduate school or } \\
\text { above }\end{array}$ & 67 & 5.63 & 0.62 & & & \\
\hline & Total & 267 & 5.70 & 0.61 & & & \\
\hline \multirow{6}{*}{$\begin{array}{l}\text { Professional knowledge of } \\
\text { preschool art teachers }\end{array}$} & 1. Elementary school & 2 & 5.38 & 0.44 & \multirow{6}{*}{1.872} & \multirow{6}{*}{0.116} & \\
\hline & 2. Junior high school & 5 & 4.98 & 0.82 & & & \\
\hline & 3. Senior high school & 27 & 5.83 & 0.58 & & & \\
\hline & 4. College or university & 166 & 5.66 & 0.62 & & & \\
\hline & $\begin{array}{l}\text { 5. Graduate school or } \\
\text { above }\end{array}$ & 67 & 5.66 & 0.76 & & & \\
\hline & Total & 267 & 5.66 & 0.66 & & & \\
\hline \multirow{6}{*}{$\begin{array}{l}\text { The entire scale of parents' } \\
\text { beliefs regarding art education }\end{array}$} & 1. Elementary school & 2 & 5.47 & 0.63 & \multirow{6}{*}{3.325} & \multirow{6}{*}{$0.011 *$} & \\
\hline & 2. Junior high school & 5 & 6.10 & 0.61 & & & \\
\hline & 3. Senior high school & 27 & 6.67 & 0.53 & & & \\
\hline & 4. College or university & 166 & 6.60 & 0.54 & & & \\
\hline & $\begin{array}{l}\text { 5. Graduate school or } \\
\text { above }\end{array}$ & 67 & 6.55 & 0.56 & & & \\
\hline & Total & 267 & 6.57 & 0.55 & & & \\
\hline
\end{tabular}

$* \mathrm{p}<.05, * * \mathrm{p}<.01$

Table 3 indicates that parents with different educational backgrounds demonstrated significant differences in the factors of preschool art courses and the entire scale of parents' beliefs regarding art education. For the preschool art courses factor, parents with an educational background of college or university, graduate school or above scored significantly higher than those with an elementary school educational background, whereas in other 
factors, no significant difference was found between parents with different educational backgrounds.

4) Analysis of the differences in the beliefs regarding art education between parents in different residential locations.

Table 4 focuses on the descriptive statistics and t-test results for the beliefs regarding art education between parents in different residential locations. The factors were categorized into two types: (1) Urban area and (2) Suburban area. A t-test was conducted to verify the differences in the beliefs regarding art education between parents residing in different locations.

Table 4. Descriptive statistics and t-test results of the beliefs regarding art education between parents residing in different locations $(\mathrm{n}=267)$

\begin{tabular}{|c|c|c|c|c|c|c|}
\hline Factors & Levels & $\mathrm{N}$ & M & SD & t-value & Sig. \\
\hline \multirow{2}{*}{ Preschool art courses } & Suburban & 28 & 6.24 & 0.41 & \multirow{2}{*}{2.107} & \multirow{2}{*}{$0.036 *$} \\
\hline & Urban & 239 & 6.02 & 0.54 & & \\
\hline \multirow{2}{*}{ Children's artistic development } & Urban & 28 & 6.34 & 0.43 & \multirow{2}{*}{2.279} & \multirow{2}{*}{$0.023 *$} \\
\hline & Suburban & 239 & 6.10 & 0.54 & & \\
\hline \multirow{2}{*}{ Parents' beliefs regarding art education } & Urban & 28 & 5.83 & 0.64 & \multirow{2}{*}{1.195} & \multirow{2}{*}{0.233} \\
\hline & Suburban & 239 & 5.68 & 0.61 & & \\
\hline \multirow{2}{*}{ Professional knowledge of preschool art teachers } & Urban & 28 & 6.02 & 0.56 & \multirow{2}{*}{3.128} & \multirow{2}{*}{$0.002 * *$} \\
\hline & Suburban & 239 & 5.62 & 0.66 & & \\
\hline \multirow{2}{*}{$\begin{array}{l}\text { The entire scale of parents' beliefs regarding art } \\
\text { education }\end{array}$} & Urban & 28 & 6.84 & 0.49 & \multirow{2}{*}{2.744} & \multirow{2}{*}{$0.006 *$} \\
\hline & Suburban & 239 & 6.54 & 0.55 & & \\
\hline
\end{tabular}

$* \mathrm{p}<.05, * * \mathrm{p}<.01$

Table 4 indicates that parents from different residential locations demonstrated significant differences in the factors of preschool art courses, children's artistic development, professional knowledge of preschool art teachers, and the entire scale of parents' beliefs regarding art education. With regard to these factors, parents living in an urban area scored significantly higher than those living in a suburban area, whereas the factor of parents' beliefs regarding art education showed no significant difference between parents from the different residential locations.

\subsubsection{Comprehensive Discussion}

The results of the differences in the beliefs regarding art education between parents with different background factors were as follows:

1) Significant differences were found in the preschool art course factor and the beliefs regarding art education between parents choosing a different type of preschool.

According to the results, parents choosing private preschools scored significantly higher in preschool art courses in reference to their beliefs regarding art education, indicating that these parents emphasized preschool art courses. This finding corresponds to Huang's (2005) research, which suggests that parents choosing private preschools place more emphasis on the content of courses and teaching methodologies than those parents choosing public preschools. Looking back at the researcher's teaching experience in the US, it was found that parents choosing private preschools emphasized courses more than those choosing public preschools. However, in all other factors, no significant difference was found.

2) Significant differences were found in the beliefs regarding art education between parents of different genders.

According to the results, there were significant differences depending on parental gender for the factors of preschool art courses, children's artistic development, professional knowledge of preschool art teachers, and the entire scale of parents' beliefs regarding art education. Female parents scored significantly higher than male parents in all of these factors. Because mothers are often the ones responsible for the cultivation and education of preschoolers, most respondents were mothers. In addition, mothers are usually more involved in their children's education than the fathers. When interviewing Israeli parents, Toren (2007) noted that mothers had more concept 
of art than fathers did. Therefore, the results also reflected that mothers' beliefs regarding art education focused on preschool art courses, children's artistic development, the professional knowledge of preschool art teachers, and the entire scale of parents' beliefs regarding art education. This result is similar to those of Hsiao and Kuo (2013), and $\mathrm{Wu}$ (2002). A significant difference was found in the factor of parents' beliefs regarding art education for parents of different genders, suggesting that parents of both genders did demonstrate differences in their beliefs regarding art education. This corresponds to the study of Zheng (2009), which shows that a significant difference can be found in parents' perspectives of after-school art classes across the different parental genders. Nevertheless, Huntsinger et al. (2011) found that Chinese American fathers believed they had greater art knowledge/skills, and that fathers also practiced art making and being a live model at home.

3) Significant differences were found in preschool art courses in reference to the beliefs regarding art education between parents with different educational backgrounds. According to the results, parents from different educational backgrounds demonstrated significant differences in the factor of preschool art courses. Parents with an educational background that was college or university, or graduate school or above scored significantly higher than those with just an elementary school background. Most of the respondents had graduated from colleges or universities. Parents with a higher level of educational background are inclined to emphasize the comprehensive education of preschoolers, and they care more for the courses and activities. As indicated by $\mathrm{Wu}(2002)$, parents with a higher educational background are more devoted to the learning activities of their children. Therefore, it was deduced that parents with education from a college, university or graduate school or above, emphasised preschool art courses in their beliefs regarding art education. Moreover, Toren (2004) found that upper class parents considered how creating artwork is good for preschooler's problem solving abilities and fosters their imagination and individual expression. However, for other factors, no significant difference was found between parents with different educational backgrounds.

4) Significant differences were found in the beliefs regarding art education between parents from different residential locations.

According to the results, parents from different residential locations demonstrated significant differences in the factors of preschool art courses, children's artistic development, professional knowledge of preschool art teachers, and the entire scale of parents' beliefs regarding art education. In their beliefs regarding art education, parents living in the urban area scored significantly higher than those living in the suburban area. Based on the opinions of interviewees in the suburban area, only a few art activities were held in the suburban area. A parent living in a suburban area had little experience in participation in art activities with their child, and did not pay specific attention to related activity information. According to a parent who lived in the urban area, art activities hosted in the urban area were diverse. Another parent had taken their child to exhibitions, such as Dali and Mona Lisa, held at the Museum of Art in the urban area. Interviewees in the urban area were often exposed to art related activities, and consequently showed a difference for preschool art courses, children's artistic development, professional knowledge of preschool art teachers, and the entire scale of parents' beliefs regarding art education.

\subsection{Differences in the Views on Learning Effectiveness of Preschool Art Education between Parents of Different Backgrounds}

This section discussed the differences in the learning effectiveness of preschool art education between parents of different backgrounds. The background factors consisted of the type of preschool, gender of the parent, educational background of the parent, and their residential location. The learning effectiveness of preschool art education was defined as satisfaction with preschool art education. Table 5 shows the descriptive statistics results of parents' satisfaction with preschool art education.

Table 5. Descriptive statistics of parents' satisfaction with art education $(n=267)$

\begin{tabular}{cccc}
\hline & $\mathrm{N}$ & $\mathrm{M}$ & $\mathrm{SD}$ \\
\hline Satisfaction & 3 & 5.78 & 2.42 \\
\hline
\end{tabular}

In Table 5, the Mean was 5.78. This indicated that the parents had a high level (scored four on the seven-point scale) for the learning effectiveness of preschool art education, implying that these parents highly identified themselves with the effectiveness of the art learning. 
4.2.1 Differences in the Learning Effectiveness of Preschool Art Education between Parents with Different Background Factors

1) Analysis of the differences in the learning effectiveness of preschool art for parents choosing different types of preschool

Table 6 is the descriptive statistics and t-test results for parental satisfaction with the art education for those parents choosing different types of preschool. The factors were categorized into two types: (1) public preschool and (2) private preschool. A t-test was conducted to verify the differences in the satisfaction with the art education for parents choosing different types of preschool.

Table 6. Descriptive statistics and t-test results for parental satisfaction with the art education for parents choosing different types of preschool $(n=267)$

\begin{tabular}{lllllll}
\hline Factor & Levels & $\mathrm{N}$ & $\mathrm{M}$ & $\mathrm{SD}$ & t-value & Sig. \\
\hline \multirow{2}{*}{ Satisfaction } & Public & 71 & 5.79 & 0.72 & \multirow{2}{*}{0.160} & 0.873 \\
& Private & 196 & 5.78 & 0.84 & & \\
\hline
\end{tabular}

$* \mathrm{p}<.05$

According to Table 6, no significant difference was found in relation to satisfaction with preschool art education between parents who chose different types of preschool.

2) Analysis of the differences in the learning effectiveness of preschool art in relation to parental gender

Table 7 shows the descriptive statistics and t-test results of the satisfaction with art education according to parental gender. The factors were categorized into two types: (1) female and (2) male. A t-test was conducted to verify the differences in satisfaction with art education according to parental gender.

Table 7. Descriptive statistics and t-test results of satisfaction with art education according to parental gender (n $=267)$

\begin{tabular}{llllllll}
\hline Factor & Levels & $\mathrm{N}$ & $\mathrm{M}$ & $\mathrm{SD}$ & t-value & Sig. \\
\hline \multirow{2}{*}{ Satisfaction } & $\mathrm{F}$ & 210 & 5.79 & 0.80 & \multirow{2}{*}{0.405} & \multirow{2}{*}{0.686} \\
& $\mathrm{M}$ & 57 & 5.74 & 0.84 & & \\
\hline
\end{tabular}

$* \mathrm{p}<.05$

According to Table 7, no significant difference was found with regard to the satisfaction with preschool art education and parental gender.

3) Analysis of the differences in the learning effectiveness of preschool art between parents from different educational backgrounds

Table 8 is the descriptive statistics and ANOVA results of the satisfaction with art education between parents from different educational backgrounds. The factors were categorized into five types: (1) elementary school; (2) junior high school; (3) senior high school; (4) college or university; and (5) graduate school or above. An ANOVA was conducted to verify the differences identified. 
Table 8. Descriptive statistics and ANOVA results of the satisfaction with art education between parents from different educational backgrounds $(n=267)$

\begin{tabular}{llllllll}
\hline Factor & Levels & $\mathrm{N}$ & $\mathrm{M}$ & $\mathrm{SD}$ & $\mathrm{F}$ & Sig. & Scheffé \\
\hline \multirow{5}{*}{ Satisfaction } & 1.Elementary school & 2 & 5.50 & 0.24 & & & \\
& 2.Junior high school & 5 & 6.27 & 0.72 & & & \\
& 3.Senior high school & 27 & 5.88 & 1.03 & & & \\
& 4.College and university & 166 & 5.78 & 0.77 & 0.684 & 0.604 & \\
& 5.Graduate school or above & 67 & 5.73 & 0.82 & & & \\
& Total & 267 & 5.78 & 0.81 & & & \\
\hline
\end{tabular}

$* \mathrm{p}<.05$

According to Table 8, no significant difference was found in relation to the satisfaction with preschool art education between parents from different educational backgrounds.

4) Analysis of the differences in the learning effectiveness of preschool art between parents according to residential location

Table 9 is the descriptive statistics and t-test results of the satisfaction with art education between parents according to residential location. The factors were categorized into two types: (1) urban area and (2) suburban area. A t-test was conducted to verify the differences in satisfaction with art education between parents according to residential location.

Table 9. Descriptive statistics and-test results for the satisfaction with art education between according to residential location $(\mathrm{n}=267)$

\begin{tabular}{lllllll}
\hline Factor & Levels & $\mathrm{N}$ & $\mathrm{M}$ & $\mathrm{SD}$ & t-value & Sig. \\
\hline \multirow{2}{*}{ Satisfaction scale with preschool art education } & Urban & 28 & 6.11 & 0.51 & \multirow{2}{*}{2.279} & \multirow{2}{*}{$0.023 *$} \\
& Suburban & 239 & 5.74 & 0.83 & & \\
\hline
\end{tabular}

$* \mathrm{p}<.05$

According to Table 9, the significant difference was found for the satisfaction with preschool art education between parents according to residential location. For the factor of satisfaction, parents living in the urban area scored significantly higher than those in the suburban area.

\subsubsection{Comprehensive Discussion}

According to the results, the type of preschool, parental gender, and parent's educational background did not show any significant differences for the learning effectiveness of preschool art education, indicating that the effectiveness was not influenced by these three factors. Similarly, Liu's (2013) research suggested that no significant differences could be found in the expectations of children's education between primary school parents of different genders and ages.

Residential location was the only factor where there were significant differences in the learning effectiveness of preschool art education. The statistics showed that parents in the urban area scored significantly higher than those in the suburban area, implying there was higher satisfaction for parents in the urban area. Elliot (1987) also noted that parents in the suburban area had low educational aspirations for their children. As suggested by interviewees in the urban area, they often took their children to art related activities in venues such as art galleries, the museum of art, the National Science and Technology Museum, and the cultural center. Interviewees in the urban area indicated that an increasing number of cultural and art events were provided on public holidays. Therefore, it can be deduced that parents in the urban area highly identified themselves with the learning effectiveness of preschool art education. 


\subsection{Correlations between Parental Beliefs Regarding Preschool Art Education and Children's Learning Effectiveness}

This section investigated the correlations between parental beliefs regarding preschool art education and children's learning effectiveness. The Pearson product-moment correlation coefficient was used to analyze whether significant differences existed. Table 10 includes all factors in relation to parental beliefs regarding preschool art education and correlations with the children's art learning effectiveness.

Table 10. Factors in relation to parental beliefs regarding preschool art education and correlations with children's art learning effectiveness $(n=268)$

\begin{tabular}{|c|c|c|c|c|c|}
\hline & \multicolumn{5}{|c|}{ Parental Beliefs regarding Preschool Art Education } \\
\hline & $\begin{array}{l}\text { Preschool Art } \\
\text { Courses }\end{array}$ & $\begin{array}{l}\text { Children's } \\
\text { artistic } \\
\text { development }\end{array}$ & $\begin{array}{l}\text { Beliefs } \\
\text { regarding } \\
\text { Preschool } \\
\text { Education }\end{array}$ & $\begin{array}{l}\text { Professional } \\
\text { Knowledge of } \\
\text { Art Preschool Art } \\
\text { Teachers }\end{array}$ & $\begin{array}{l}\text { The Entire } \\
\text { Scale of } \\
\text { Parents' } \\
\text { Beliefs } \\
\text { regarding } \\
\text { Art } \\
\text { Education }\end{array}$ \\
\hline $\begin{array}{lr}\text { Children's } & \text { art Correlation } \\
\text { learning } & \text { Coefficient }\end{array}$ & 0.409 & 0.299 & 0.378 & 0.334 & 0.423 \\
\hline effectiveness Significance & $0.000 * *$ & $0.000 * *$ & $0.000 * *$ & $0.000 * *$ & $0.000 * *$ \\
\hline
\end{tabular}

$* \mathrm{p}<.05, * * \mathrm{p}<.01$

4.3.1 Correlation Analysis for Parental Beliefs regarding Art Education and Children's Art Learning Effectiveness

According to Table 10, all factors in relation to parental beliefs regarding art education were significantly correlated to the children's art learning effectiveness. The highest correlation $(0.423)$ was found between the entire scale of parents' beliefs regarding art education factor and the children's art learning effectiveness.

\subsubsection{Comprehensive Discussion}

According to Table 10, higher beliefs regarding art education would result in parents' higher identification with the children's art learning effectiveness. The six interviewees in this study demonstrated that they identified with the teachers' methods. Their children were provided with a higher frequency of creative opportunities in their preschool, and the children's artworks were fabulous. The interview reports corresponded to these quantitative data. Both Anning (2002) and Kantner and Hoffman (1992) found there was positive parental support/attitude towards positive preschoolers' art making experiences. Furthermore, Rose et al. (2006) noted that parents had a vital role in shaping preschoolers' art experience and artwork.

\subsection{Predicted Results of Parents'Beliefs Regarding Art Education and Children's Learning Effectiveness}

This section investigated the predicted results of parents' beliefs regarding preschool art education and the children's art learning effectiveness. The factors in relation to beliefs regarding art education were adopted as prediction factors and children's art learning effectiveness as a dependent factor. A multiple regression analysis was conducted to understand the predictive power of the factors relating to parental beliefs regarding art education on children's art learning effectiveness. Table 11 shows the factors of parental belief regarding art education and the children's art learning effectiveness. 
Table 11. Multiple regression of the factors in relation to parents' beliefs regarding art education and the children's art learning effectiveness $(n=267)$

\begin{tabular}{llllll}
\hline & B & SD & Beta & t-value & Sig. \\
\hline Constant & 1.619 & 0.567 & 2.857 & $0.005 * *$ \\
Preschool art courses & 0.323 & 0.158 & 0.213 & 2.040 & $0.022 *$ \\
Children's artistic development & -0.119 & 0.148 & -0.079 & -0.807 & 0.420 \\
Parents' beliefs regarding art education & 0.151 & 0.133 & 0.115 & 1.134 & $0.048 *$ \\
Professional knowledge of preschool art teachers & 0.030 & 0.159 & 0.025 & 0.189 & 0.850 \\
The entire scale of parents' beliefs regarding art education & 0.290 & 0.366 & 0.199 & 0.793 & 0.428 \\
$\mathrm{R}$ & 0.447 & & & \\
$\mathrm{R} 2$ & 0.199 & & & \\
\hline $5, * * \mathrm{p}<.01$ & & & &
\end{tabular}

$* \mathrm{p}<.05, * * \mathrm{p}<.01$

\subsubsection{Predictive Analytics of Parents' Beliefs regarding Art Education and Children's Art Learning Effectiveness}

The factor of preschool art courses demonstrated the highest predictive power with a standardized regression coefficient of 0.213 , followed by the factor of parents' beliefs regarding art education with a standardized regression coefficient of 0.115 . Moreover, Table 11 shows that all the factors in relation to parents' beliefs regarding art education were capable of explaining the $19.9 \%$ coefficient of variation for the children's art learning effectiveness.

\subsubsection{Comprehensive Discussion}

According to the research results, significant predictive power was found for the factors of parents' beliefs regarding art education and children's art learning effectiveness. The preschool art course factor possessed the highest predictive power, suggesting that these courses could positively predict children's art learning effectiveness. Most parents said: "The teachers' devotion is represented in the artwork brought home by my child". In addition, a parent who lived in the urban area said: "I identify myself with the guidance and creativity-oriented methods adopted by the preschool teacher". In Hsiao's (2010) study, it also showed that, after conducting a series of picture book courses, parents had a highly positive attitude towards children's art making experience and artworks. Moreover, Burkitt et al. (2010) mentioned parents who recommend that art education should be integrated with other taught subjects. Most Taiwanese preschool teachers implemented a theme-based curriculum and integrated art activities with other subjects to obtain the best learning effects. Therefore, it was testified that the preschool art course factor could positively predict children's art learning effectiveness.

\section{Conclusion}

\subsection{Differences in the Beliefs regarding Art Education and Parents with Different Background Factors}

The significant differences were found in the beliefs regarding art education between parents who chose a different type of preschool, were a different gender, educational background, and residential location.

According to the results, parents choosing private preschools, compared to those choosing public preschools, put a greater emphasis on the beliefs regarding preschool art courses in art education. Female parents scored significantly higher than male parents in the factors of preschool art courses, children's artistic development, professional knowledge of preschool art teachers, and the entire scale of parental beliefs regarding art education, indicating that these factors were influential on mothers' beliefs regarding art education. Parents who had an educational background of college or university or graduation school or above also placed more emphasis on preschool art courses.

\subsection{Differences in the Learning Effectiveness of Preschool Art Education in relation to Parents from a Different Background}

The location of the family residence showed a significant difference in children's art learning effectiveness. According to the results, parents living in the urban area obtained significantly higher scores than those from the suburban area, indicating there was a higher level of satisfaction with children's learning effectiveness in relation to preschool art education for parents in the urban area. 


\subsection{Significant Correlations Were Found between Parents' Beliefs regarding Art Education and Children's Art Learning Effectiveness}

According to the research results, the factors of parents' beliefs regarding art education and predictions of the children's art learning effectiveness possessed significant predictive power. Therefore, parental beliefs regarding art education could effectively predict a child's learning effectiveness. Amongst all the factors, preschool art courses had the most effective predictive power, indicating that this factor could positively predict children's art learning effectiveness.

\section{Suggestions}

\subsection{Suggestions for Government Institutions}

The findings of this study indicated that parents in the urban area showed a higher level of satisfaction with the learning effectiveness of preschool art education, compared to those in the suburban area. Therefore, this study suggests that the suburban area government hosts more art activities during the holidays, such as arts festivals. In addition, local museums should cooperate with foreign museums to circulate artworks by famous artists for families in the suburban area to appreciate. Moreover, preschool teachers in the suburban area could organize educational activities for parents and children in order to enhance the parental satisfaction with art learning effectiveness.

\subsection{Suggestions for Preschool Teachers}

The findings of this study indicated that those parents choosing a private preschool placed a higher emphasis on preschool art courses when compared to parents of public preschools. Moreover, parents' higher education backgrounds indicate that they put more emphasis on preschool art courses. Therefore, it is suggested that public preschool teachers share more frequently the creative artwork of the children with their parents, and promote the importance of preschool art education during parent-teacher conferences. Furthermore, parents and children should be invited to school anniversaries or arts festivals in order to participate in arts activities, thereby enhancing the importance of preschool art courses in the eyes of public preschool parents.

\subsection{Suggestions for Preschool Parents}

The findings of this study indicated that female parents scored higher than male parents in preschool art courses, preschool artistic development, professional knowledge of preschool art teachers, and the entire scale of parents' beliefs regarding art education. Therefore, it is suggested that fathers pay more attention to their children's art courses and to the teachers' professional knowledge of art. Fathers should also spend more time listening to their children, and try to understand the content and motivation behind their artwork. Moreover, it is suggested that fathers show positive encouragement when children share their creative artwork.

\subsection{Suggestions for Future Study}

If researchers will do the same study outside of Taiwan, researchers have to be aware of the differences between suburban and urban areas, parent's gender, and parent's educational background. Moreover, researchers also can interview more parents to gather more in-depth insights on participant attitudes and thoughts of children's art education.

\section{Reference}

Anning, A. (2002). Conversations around young children's drawings: The impact of the beliefs of significant others at home and school. International Journal of Art \& Design Education, 21(3), 197-208. http://dx.doi.org/10.1111/1468-5949.00317

Burkitt, E., Jolley, R., \& Rose, S. (2010). The attitudes and practices that shape children's drawing experiences at home and at school. International Journal of Art and Design Education, 29(3), 257-270. http://dx.doi.org/10.1111/j.1476-8070.2010.01658.x

Elliot, J. (1987). Rural students at risk. Elmhurst, IL: North Central Regional Educational Laboratory.

Hsiao, C. Y. (2010). Enhancing children's artistic and creative thinking and drawing performance through appreciating picture books activities. The International Journal of Art \& Design Education, 29(2), 143-152. http://dx.doi.org/10.1111/j.1476-8070.2010.01642.x

Hsiao, C. Y., \& Kuo, T. Y. (2013). Investigating kindergarten parents' selection of after-schoolvisual art education settings in Taiwan. Journal of Education and Learning, 2(4), 208-219. http://dx.doi.org/10.5539/jel.v2n4p208

Huang, T. W. (2005). A study of parents' education expectations and choice of early childhood education choices 
(Unpublished master's thesis). National Kaohsiung Normal University, Kaohsiung.

Huntsinger, C. S., Jose, P. E., Krieg, D. B., \& Luo, Z. (2011). Cultural differences in Chinese American and European American children's drawing skills over time. Early Childhood Research Quarterly, 26, 134-145. http://dx.doi.org/10.1016/j.ecresq.2010.04.002

Kantner, L., \& Hoffman, S. (1992). Parents' perception of their children's early art experiences. Visual Arts Research, 18(1), 50-56.

Koster, J. B. (2005). Growing artists: Teaching art to young children (3rd ed.). Australia: Thomson/Delmar Learning.

Lai, Y. L. (2011). A case study of children's art learning with parents (Unpublished master's thesis). National Hsinchu University of Education, Hsinchu.

Lee, C. L., \& Lee, H. I. (2006). Early childhood art education. Kaohsiung: Li-Wen.

Lee, M. W. (2006). Research of the factors of parents' choice for children's extra-curricular activities:Instance of public kindergarten in Taipei county (Unpublished master's thesis). National Taipei University of Education, Taipei.

Liu, H. H. (2013). A study on the relationship between Pingtung county elementary schoolparents' educational expectations for their children and their attitude toward learning skills and arts (Unpublished master's thesis). National Pintung University of Education, Pintung.

Lowenfeld, V. (1954). Your child and his art: A guide for parents. New York: Macmillan.

Lowenfeld, V., \& Brittain, W. L. (1987). Creative and mental growth (8th ed.). New York: Macmillan.

MOE. (2013). Creative and aesthetic Taiwan: The five year aesthetic education program. Retrieved from http://epaper.edu.tw/topical.aspx?topical_sn $=824$

MOE. (2013). Early childhood education and care act. Taipei: The Ministry of Education.

MOE. (2013). Temporary curriculum guidelines for preschool childcare and education. Taipei: The Ministry of Education.

Nunnally, J. C. (1978). Psychometric theory (2nd ed.). New York: McGraw-Hill.

Pai, T. C. (2014). Investigating parents' beliefs and attitudes toward visual art education in kindergartens (Unpublished master's thesis). National University of Tainan, Tainan.

Rose, S. E., Jolley, R. P., \& Burkitt, E. (2006). A review of children's, teachers' and parents' influence on children's drawing experiences. International Journal of Art \& Design Education, 25(3), 341-349. http://dx.doi.org/10.1111/j.1476-8070.2006.00500.x

Sauro, J. (2010). Should you use 5 or 7 point scales? Retrieved from http://www.measuringusability.com/blog/scale-points.php

Toren, Z. (2004). Art curriculum, learning materials, and cultural capital in the Israeli kindergarten. Art Education, 45(3), 206-220.

Toren, Z. (2007). Attitude towards artwork in the Israeli kindergarten and the reproduction of social status. Studies in Art Education, 48(2), 172-188.

Wu, C. F. (2002). A study of parental education and occupation on parenting beliefs and participation on children (Unpublished master's thesis). National Chiayi University, Chiayi.

Zheng, H. L. (2009). The study of parents' perceptions and consumer behavior in Pingtungcounty elementary school (Unpublished master's thesis). National Pintung University of Education, Pintung.

\section{Copyrights}

Copyright for this article is retained by the author(s), with first publication rights granted to the journal.

This is an open-access article distributed under the terms and conditions of the Creative Commons Attribution license (http://creativecommons.org/licenses/by/3.0/). 